\title{
Leadership Excellence and Gender in Organizations
}

\section{Queen bees, mother hens, and king apes: A multi-source and cross-cultural examination of gender differences in supervisor- subordinate relations}

\author{
Samantha C. Paustian-Underdahl \\ spaustia@fiu.edu \\ Eden B. King \\ Steven G. Rogelberg \\ Zoa Ordóñez \\ Ines Weichert \\ See next page for additional authors
}

Follow this and additional works at: https://docs.lib.purdue.edu/cgg

Part of the Communication Commons, Human Resources Management Commons, Organizational Behavior and Theory Commons, Political Science Commons, Psychology Commons, and the Sociology Commons

\section{Recommended Citation}

Paustian-Underdahl, S.C., King, E.B., Rogelberg, S.G., Ordóñez, Z., Weichert, I., Rasch, R., and Gentry, W.A. (2016). Queen bees, mother hens, and king apes: A multi-source and cross-cultural examination of gender differences in supervisor-subordinate relations. Paper presented at Closing the Gender Gap: Advancing Leadership and Organizations. DOI: 10.5703/1288284316070

This document has been made available through Purdue e-Pubs, a service of the Purdue University Libraries. Please contact epubs@purdue.edu for additional information. 


\section{Queen bees, mother hens, and king apes: A multi-source and cross-cultural examination of gender differences in supervisor-subordinate relations}

\section{Authors}

Samantha C. Paustian-Underdahl, Eden B. King, Steven G. Rogelberg, Zoa Ordóñez, Ines Weichert, Rena Rasch, and William A. Gentry 
In 2 studies that draw from literature on the 'queen bee' effect, the 'crabs in the barrel' mentality, and social identity-based theory, the authors answer a call in the literature to reconcile previous discrepancies regarding when and how the demographic composition of supervisorsubordinate dyads relates to perceived supervisor support. We argue that supporting members of the higher status group, while distancing oneself from the lower status group is a contextually induced way female and racial minority employees may cope with identity threat in the workplace. Our results supported the hypotheses, indicating that this self-distancing effect only emerges in settings where gender or racial identities may be considered threatened (in organizations with higher perceived gender discrimination; Study 1, or more adverse diversity climates; Study 2). Such results are particularly important and timely given the recent ample attention in popular media and academic outlets regarding the 'queen bee' effect, the 'crabs in the barrel' mentality, and diversity-valuing behavior of leaders. The current research suggests that such behaviors are not generalizable to all female or minority employees; rather, this effect seems to be context-driven. 